\title{
AZ ÉRTELMEZÉS SZABADSÁGA
}

\author{
Balázs Zoltán \\ (Budapesti Corvinus Egyetem, ELKH TK Politikatudományi Intézet)
}

A recenzió beérkezett: 2020. április 26., véglegesítve: 2020. április 26.

Szabó Márton könyve a szerző igen jelentős életmúvének egyik összegzése; különféle írások, könyvek, fejezetek célszerüen elrendezett egysége, saját szavaival kísérleti monográfia, ambíciója újfajta bevezetést nyújtani a politikatudományba. A könyvhöz vezető utat a bevezető fejezete kimerítő módon mutatja be. Szabó Márton munkássága jól ismertnek mondható a magyar politikatudomány berkeiben, s ebben a bevezetésben bepillantást nyerhetünk egy hatalmas tudásanyag formálódásáról, fejlődéséről, változásairól. Természetesen a lehetetlenséggel határos mindenre kiterjedő bírálattal próbálkozni, ezért itt csak saját érdeklődési területem és kompetenciáim határai között maradva és ezekre támaszkodva fogalmazok meg néhány észrevételt, kritikát és kérdést.

Politikaelmélet versus társadalomelmélet. A legáltalánosabb szinten maradva: a szöveg olvasása közben újra és folyton fölmerült bennem az a kérdés, hogy a szerző szerint vajon mi különbözteti meg a politikaelméletet a társadalomelmélettől, a politika világát a társadalom egészének világától. Választott és meggyőződésének megfelelő metodológiai és ontológiai föltevései ugyanis messze túlmutatnak a politikán. (Egyáltalán nem mellékes, hogy a magyar politikatudományban is, de alighanem a magyar társadalomtudományban is kivételes, hogy egy teoretikus ennyire alaposan és konzekvensen végiggondolja az ontológia kérdéseit.) A bevezetésben mindenesetre ezt olvashatjuk: „A diszkurzív szemlélet szerint a politika elsősorban és alapvetően egy közösség nyilvános, közös, értelmezett és szabályozott élete és tevékenysége" (23., eredeti kiemelés). Ebből a meghatározásból már jól érzékelhető a problémám: ennek ugyanis tökéletesen megfelel egy azték kultúra éppúgy, mint a köztársasági Róma; megfelel egy tetszôleges, szervezetileg fölismerhetô keresztény felekezet éppúgy, mint egy sportszervezet; egy nagyvállalat éppúgy, mint egy hadsereg. A szerző - természetesen helyeselhető konzisztenciával - a későbbiekben is ragaszkodik ehhez a felfogáshoz, újra és újra elutasítva például az objektív-szubjektív megkülönböztetést, ismételten kiemelve, hogy a társadalmi tényeket az egyéntől függetlennek, de mindig kontingensnek tartja; hogy a beszédre és a nyelvre koncentrálva tudjuk a társadalmi viszonyokat valódi viszonyokként elképzelni és ábrázolni. De minduntalan előjön az alapprobléma: hol és hogyan válik ez a 
társadalomelméleti-antropológiai felfogás politikaivá? A szerző természetesen jól ismeri a marxizmus társadalomfilozófiáját: abból a politikai cselekvés és általában a politika autonómiája, sajátszerúsége köztudottan hiányzik, pontosan azért, mert kiinduló föltevései szerint erre szükség sincs. Számomra úgy tűnik, hogy ebben a formában a diszkurzív politikatudomány is túllövés a célon. Noha Szabó Márton sokszor és sokat foglalkozott Carl Schmittel, s ebben a könyvben is előkerült az összes ismert schmitti fogalom és probléma, ideértve természetesen a politikai minőség mibenlétét is, a szerző mégis adós marad az ontológiai kérdés megválaszolásával. Értem, hogy nem kíván cselekvéselméletet megfogalmazni (69. oldal), s bár ezt annyiban kvalifikálja, hogy nem 'szociológiai' cselekvéselméletet kíván mûvelni, 'politikait' sem mûvel - noha ezeket a kérdéseket egy ilyen ívư munkában érzésem szerint nem lehet megkerülni. Mert ha megkerüljük, valójában már nem a politikáról írunk, hanem minden értelmezett és értelmezésekkel leírt társadalmi jelenségről (legföljebb több a politikainak ismert példa). Ezzel viszont olyan nagyra tágítottuk a lencsét, hogy abban már mindent egyszerre látunk. A látvány pedig lehet impozáns, de az elemző hozzáadott értéke már nem látszik.

Megérteni versus tudni. 'Nincsen értelmezetlen társadalmi tény, másként fogalmazva: a társadalmi tények mindig értelmezettek.' (A szerző megfogalmazásával: „A társadalmi tények kontextuálisak és konstruáltak.” - 579. oldal.) Ezt az állítást nehéz vitatni. Arról persze már lehet módszertani vitát folytatni, hogy vannak-e nem társadalmi tények: mondjuk a nem emberi környezetre vonatkozó tudományos állítások, igazságok (ideértve az emberre vonatkozó fizikai tények megállapításait is, például, hogy erősen kopaszodom); illetve, hogy ezeket hogyan lehet megkülönböztetni a társadalmi tényektől. Most azonban nem ezt a vitát kívánom kinyitni, hanem az értelmezés filozófiai státusának kérdését vetem föl. A szerző kimerítően ismertet különböző szerzőket, módszertani iskolákat, amelyek mind megadnak egy-egy értelmezési keretet. De mindegyik valamilyen önmagán túlmutató tényre utal (a tényre utaló szavakat, fogalmakat a 67. oldalon a szerző föl is sorolja, példa: létezik olyan, hogy szimbólum, létezik olyan, hogy diskurzus, stb.). Nekem azonban éppen ezért hiányzik a politikai filozófia alapító atyjának, Szókratész-Platónnak az alapkérdése: igazságos-e, ami az erősek érdekében áll? Akár igennel, akár nemmel felelünk, vagy bármelyik hipotézist állítjuk is föl, azaz bármelyiket igyekszünk is tényként igazolni vagy cáfolni, bizonyosan szükségünk lesz a hermeneutikára, az értelmezés tudományára. Ebben szofisták és filozófusok egyetérthetnek. De a magam részéről kétlem, hogy az értelmezés mint tevékenység, reflexiós mód kimerítő és főleg megnyugtató módon megválaszolná a kérdést. Ugyanis tudni, nem pedig csak érteni akarunk. A tényeket ismerni lehet. Az igazságot - mi az igazságosság, mi az érdek; mi az igazságosságról folytatott vita - viszont tudni is. S ha ez így van, akkor a diszkurzív szemlélet valamilyen határokba ütközik: ismeretet tud szolgáltatni, tudást azonban nem, vagy csak töredékesen. Ezek után nem lehet meg- 
lepő, hogy egyfelől teljes mértékben egyetértek Szabó Mártonnak az aktivista tudományt illető fenntartásaival, másfelől nem gondolom, hogy a tudományospártatlan megismerési szándék mindig 'csak' értelmezésekbe torkollik. Ekkor ugyanúgy föloldódik a tudomány a politikában, mint amikor azt direkt politikai célokra igyekszünk alkalmazni. A politológus szerepe nem lesz más, mint lehetséges, esetleg új, netán érdekes, még'netánabban' politikailag hasznos értelmezések kidolgozója. Megfordítva: abból, hogy a tudományos nézőpont - ami nem azonos a politikáéval - politikailag hasznos lehet (akár úgy is, hogy - s ebben megint egyetértek a szerzővel - 'fölszabadít', 'megszabadít' bizonyos uralkodó diskurzusok látszólagos kényszerétől), nem következik, hogy a tudomány lényegében ugyanúgy csak narratívákat, diskurzusokat állít elő vagy folytat, mint a szúkebb értelemben vett politikai tér résztvevői.

Értelmezés versus döntés. Nem vagyok teljes mértékben meggyőzve arról, hogy Michael Oakeshott nézetei hézagmentesen illeszkednek Szabó Márton felfogásához, aki Oakeshott-ot mindig úgy idézi, hogy az illeszkedés résmentesnek tûnjön. Ez persze még nem baj: a munka nem Oakeshott-elemzés, tehát a szerző szuverén módon dönthet róla, hogy az idézett szerző érveit miként használja. Nem is az értelmezés hitelességével van gondom, hanem a tartalmi koherenciával. Kétségtelen, hogy Oakeshott nagy ellenfele volt a politikát teljesen racionális tevékenységnek tekintő felfogásnak, amelyet szívesen azonosított a tudománnyal vagy a tudományos megközelítéssel; az sem vitás, hogy a retorikát, a politikai érvelést a politika igazi anyagának tekintette; de Oakeshott - ahogy Szabó a 149. oldalon maga is idézi - a politikában a mérlegelés, a választás döntéseit is ugyanennyire hangsúlyozta. Mármost igaz, hogy minden döntéshez tartozik valamilyen értelmezés, előzetes vagy utólagos magyarázat, igazolás, kommentár; de a döntés egyszerúen más státusú tevékenység, helyesebben tett, mint a vitatkozás, az eszmecsere, az indokolás, a meggyőzés, a szónoklás, vagy akár a magányos emlékirat-írás. A második könyv vége felé ez a gondolat újra előkerül, itt Carl Schmitt kapcsán: a szavak, írja Szabó Márton, végső soron eszközök (170. oldal); olykor kimondásuk több, mint megszólalás: cselekvés. Az értelmezés is cselekvés persze, de csak egyike a lehetséges cselekvéseknek. Úgy gondolom, hogy a cselekvéselmélet végső soron kivezet a diskurzuselméletből, a diszkurzív politikatudományból, akár akarjuk, akár nem. Igaz, Szabó nem 'szociológiai cselekvéselméletet' kíván kidolgozni (ezt már idéztem), mégsem tudja egészen megkerülni, hogy a kontingencia, a kivételesség, a képviselet/helyettesítés, a példaadás és más - nagyon is értékesen és érdekesen bemutatott és elemzett - cselekvéseiben valami tartalmit is mondjon a politikai, a politikai cselekvés jellemző, fölismerhető, a politikát meghatározni látszó minőségéről. Úgy látom, hogy ezek az Oakeshott-Arendt-Weber-Schmitt tengelyen elhelyezkedő alfejezetek nem illeszkednek igazán jól a diszkurzív politikatudományhoz, ahogyan azt a szerző programszerüen kifejti és megfogalmazza. 
Intézmények. A harmadik könyv a „Keretek” címet viseli. Szabó Márton az intézményekre vonatkozó bevett politikatudományi megközelítések mellé a diszkurzív politikatudomány lehetőségeit is föl kívánja tárni. Számomra némileg fölöslegesnek tûntek a különböző elméletek összefoglalásai, ilyenekből nagyon sok van már. Ami hiányzik viszont, s itt a hiányt kivételesen megemlítem, az a John Searle nevéhez köthető intézményelmélet („What is an Institution?" Journal of Institutional Economics, 2005), illetve annak számos leágazása; valamint az institucionalista közgazdaság-tudomány, amely szintén könyvtárnyi irodalmat tudhat magáénak. Zavarónak találtam a racionális döntések elméletének bemutatását, mert bár Szabó láthatóan törekszik a pontos és hiteles megfogalmazásra (190. oldal), másutt mégis közel kerül ahhoz, amit maga nevez 'parodisztikus interpretációnak' (186. oldal), persze ott a diszkurzív politikatudomány egyes bírálóinak fölróva ezt a hibát. A racionális döntések elmélete ugyanis nem 'teória' (193. oldal), legalábbis képviselői szerint, hanem ugyanolyan módszertani-elemzési keret, mint bármilyen más hasonló magyarázati séma, azzal a különbséggel, hogy azoktól eltérően igen szikár, konzisztens és ellenőrizhető axiómarendszerrel dolgozik. Ha tetszik, egyfajta diskurzus (akkor persze nem egészen érthető, hogy a szerző miért akar szubsztantív bírálatot megfogalmazni vele kapcsolatban). Természetesen vitatható az a szerzői megállapítás is, hogy a preferenciák eredetére nézve ezzel a módszerrel semmit sem mondhatunk; számos idevágó elmélet létezik. De ha így is volna - azaz egy szúkebb értelemben a preferenciákat egyszerúen adottnak vesszük -, még akkor sem kell lemondani arról a föltevésről, hogy a preferenciákat végső soron az egyén határozza meg, mégpedig éppen azáltal, hogy velük kapcsolatban döntést hoz. Persze nem föltétlenül tudatos, átgondolt értelemben (még egy filozófus sem képes erre), hanem egyszerűen abban a korlátozott peremfeltétel-értelemben, hogy az egyén helyett más nem tud dönteni. Egy totális diktatúrával való szembeszálláshoz ritka bátorságra van szükség; mégsem mentjük föl egészen az alkalmazkodók tömegeit. Ezért beszél a közgazdaság-tudomány kinyilvánított preferenciákról: azt, hogy mi a preferenciám, voltaképpen magam is csak abból tudom meg, hogy döntök (választok), illetve ahogyan döntök. (Nem egészen érdektelen az analógia a schmitti politikafelfogással: a döntés maga a tartalom.) Továbbá a tökéletes informáltság ma már csak alesetnek számít, igen komplex játékelméleti modellek vannak a tökéletlen informáltság eseteire is (paradigmatikus példa a tőzsde), valamint a különböző stratégiai-valószínúségi cselekvésekre, amelyekben a cselekvők csak föltételezésekkel élhetnek a többi cselekvő magatartására nézve. Claus Offe ezen a téren (a racionális cselekvő modelljének bírálójaként) valószínúleg nem a legjobb forrás. (Tévedés például, hogy a haszonmaximalizálás azért „nem lehet a cselekvés iránymutatója" - idézi Offét a szerző ugyanott (193. oldal) -, mert nem mindig sikerül maximalizálni a hasznot: ez non sequitur.)

Azonban mindez nem annyira fontos, hiszen a szerző konstruktív mondanivalója a diszkurzív elemzés használhatósága a szervezetek, intézmények világá- 
ban. Ebből a szempontból nem találtam teljesen meggyőzőnek az okfejtést. Úgy vélem, hogy nagyrészt túlságosan is általános szinten marad, ott viszont nem mond igazán újat. Igazán sokféle szervezetelmélet van, s egyáltalán nem állja meg a helyét, hogy „minden megelőző szervezetelméleti kutatás 'a természettudomány valóságértelmezésének mintájára fogja fel a társadalmi valóságot'" (Szabó Márton Gelei Andrást idézi, 236. oldal). Hogy más példát ne hozzak: Ronald Coase már 1937-ben az Economicában megjelent írásában (The Nature of the Firm) föltette azt a kérdést, hogy mi is a vállalat; válasza pedig éppen a 'hagyományos' (weberi, bürokratikus) szervezetelmélet teljes félretevéséből indult ki. Elemzésére épült később a piacok és hierarchiák (a szintén Nobel-díjas Oliver Williamson híres könyvének címe: Markets and Hierarchies) dualitásával operáló institucionalista közgazdaságtan. Egyszóval a szervezetek kutatásában nem csak két paradigma van. Ezért sokkal érdekesebb és távlatosabb részeknek tartom azokat, ahol konkrét politikai elemzések közelébe kerülünk. Kifejezetten szórakoztató volt olvasni a magyar rendszerváltás történetéből azt a kis részt, ahol a KDNP-nek az ellenzéki kerekasztalhoz való csatlakozásáról (kooptálásáról) vitatkoztak az érintettek: itt tényleg az érvek, a vita, az értelmezések döntötték el, hogy a szóban forgó valami tényleg párt-e, s ennek egyik fontos kritériuma az volt, hogy szervezetként létezik-e már. Való igaz, a politikatudománynak (is!) szembe kell néznie azzal, hogy az általa tanulmányozott entitások (pártok, kormányok, államok, mozgalmak) vajon szervezetek, intézmények-e, s ha igen, akkor miképpen. Azt hiszem azonban, hogy a politikai ontológia régóta létező téma, legföljebb nem így hívjuk; hiszen ma a politikai rendszerek mibenlétének, természetének osztályozása (ismét?) a legdivatosabb témák közé tartozik. Ebből a tekintetből a hatalomgyakorlás szervezettsége és szervezeti megoldásai különösen is relevánsak. Egy szó mint száz: a harmadik könyv teljesen releváns kérdéseket feszeget, megítélésem szerint talán túl sok időt vesztegetve a szervezetés intézményelmélet egészére, s ezzel mégis leegyszerúsíti az eleve áttekinthetetlenül nagy szakirodalmat. Viszont nagyon termékenynek látszanak a későbbi kutatások szempontjából azok az észrevételek, amelyek a leíró, s nem is annyira politikatudományi, mint inkább jogi, közjogi, alkotmányjogi paradigma meghaladásának szükségességét és módszereit érintik.

Összefoglalásképpen az alábbiakat tartom fontosnak kiemelni: Szabó Márton mûve mindenképpen mérföldkő, egyszerre összegző és inspiratív, utat mutató munka. Mintaszerúen tartózkodik önmagát mint egyedül lehetséges megközelítést bemutatni; az idézett és fölhasznált szerzőket, klasszikusokat inkább integrálni igyekszik, semmint bírálni őket. A magyar és a nemzetközi politikatudományban is ritka - inkább kiveszőfélben lévő - komplexitással és átfogó igénnyel lép föl, így minden olyan olvasó számára ismeretlen távlatokat nyit, aki a politikatudomány valamelyik részterületét múveli. Szinte bizonyos, hogy elképzelései és ötletei sokakat fognak még inspirálni és eligazítani; ennél többre egyetlen szerző sem vágyhat. 